\title{
集会報告
}

第2回ICSU-UNESCO国際会議 : 科学における電子出版

日 時：2001年2月20日 (火) 〜23日 (金)

会 場 : パリユネスコ本部

主 催 : 国際科学連合会議 (ICSU), ユネスコ (UNESCO)

\section{<背景 >}

第1回会議は1996年2月に同じくユネスコ本部で 開催された。年々科学情報か増大している中, 科学 技術情報の一次的流通手段として, また学術コミュ ニケーションの手段としての電子出版に関して 種々の議論と提案が光こでなされた。電子雑誌で あっても従来の雑誌記事掲載にあたってのピアレ ビューの厳格な実施が必要であること，電子資料の アーカイブの設定の必要性, 電子出版コストと利益 に関する研究が求められていること, 電子出版への アクセスのためのインフラ整備の必要, 開発途上国 が電子出版にアクセスできるための何らかの援助 の検討などが第1回会議の勧告として出された。今 回は光の2回目の会議である。第1回で出された勧告 の内容について同樣の議論と, 第1回からの時間経 過の中で出現した実践と進捗も含めて樣々な発表 が出され，かつ議論が展開された。

\section{<発表項目 $>$}

会議第1日目は吉川弘之ICSU現会長の基調講演， 松浦ユネスコ事務局長の講演（代理による），EU Commissioner for Researcherの科学情報の効果的流通 の重要性についての講演, さらに本国際会議の総合 議長であるSir Elliot ICSU Press議長の, 第1回会議か らの電子出版にかかわる事象の進展についての報 告があった。第1日目の午後から第 2 日目，3日目の 午前中は合計20の一般発表, 両日の午後の分科会お よび最終日の分科会のまとめ, 会議の勧告, 科学に 果たす電子出版の有益性に関する科学者および出 版社の見解が発表された。

会議を概要するならば，学術情報の流通にとって 電子出版は必要な，かつ前進すべき手段である。一 つに, 弚れが学術研究内容の3次元表現, 動画的表 示が可能であること, 論文相互および出版物間での リンクがはれること, 乥して物理学, 数学分野で有 効なe-printサーバにみられるように従来的な出版プ ロセスで不可欠なピアレビューなしで速報的に研 究成果をWeb上で一般に公開できることなどによ
る。しかし一方で, 生物医学系の出版では電子出版 であろうとも従来的なものであろうともピアレ ビューは不可欠であることも強調された。すなわ ち, プレプリントサーバ, ピアレビューについては 科学技術医学 (STM) 全般にわたる統一的なアプ ローチは模索できなかったものの両面からの議論 がなされた。今回会議では電子出版のコスト, 経済 的側面, 電子環境下でのデータベース, 研究成果の 法的 (著作権など) およびプライバシー・倫理的課 題が新たに論じられた。経済的側面に関連して, 前 回に引き続き電子出版, 電子流通の恩恵に浴し難い 開発途上国に対する財政面での対応はいかにある べきか提起があった。電子出版およびWebの透明性 の進展 ,アグリゲータの登場などで, 商業系出版社 , 学協会系の出版および図書館・ライブラリアンも光 の機能と役割か変化していくし，またせざるを得な い状況であるといったことが会議で浮き彫りにさ れた。

以下に電子出版に関する一般発表の題目と発表 者および分科会のタイトルを示す。

1) 一般事項

科学出版の新システム原理

David Shulenburger: University of Kansas, USA

電子的コミュニケーションの科学への寄与

Ana Maria Cetto: Instituto de Fisica, UNAM, Mexico 科学杂隹誌の役割と形態の変化

Michael Keller: Univerisity Librarian, Standford University, USA

2) 科学コミュニティからの反応 グローバルな知識ネットワークの創造

Pau Ginsparg: Los Alamos National Laboratory, USA 生物科学における電子出版と情報統合のための 欧州をべースとしたプラットフォーム

E-BioSciLes Grivell: European Molecular Biology Organization

電子出版 SciELOモデルとラテンアメリカ,カリ ブ海諸国の科学杂隹誌の利用とインパクトの測定 Abel Packer: SciELO, FAPESP/BIREME Project, 
Director, BIREME/PAHO/WHO, Brazil

3 ) 経济面での課題

科学杂隹誌の電子出版の新しい経済モデル

Pieter Bolman: President, Academic Press USA

アジア・太平洋地域及び第三世界における科学 出版

Kok Khoo Phua: World Scientific, Singapore

日本における学会等非営利機関の役割

Kunio Tada: Yokohama National University

電子環境が科学上の課題への公的関与に及ぼす

インパクト

Sir John Maddosx: Former Editor, Nature, UK

4) 法的および倫理的課題

著作権およびデータベースに関する新規法律と 弚れが科学に与えるインパクト

Thomas Dreier: Professor of Intellectual Property, Karlsruhe Technical University, Germany

電子出版 : プライバシーを含む倫理的課題

Richard Smith: Editor, British Medical Journal, UK

$5)$ 電子出版における課題

ニューロインフォマティックス:IT時代における 神経科学研究の关れへの該当分野

Stephen H Koslow: Associate Director, National Institute of Mental Health, USA

大型データ集合の出版と利用

John Rumble: President, CODATA, National Institute of Standards and Technology, USA

電子出版の新規な実践 : 質の維持および統合性 の保証に関する方法
Joost Kirez: KRA Publishing Research and Van der Waals-Zeeman Instituut of Amsterdam

6) 二次出版体制

電子環境におけるアグリゲータの重要性

Simon Inger: Catch Word Ltd.,UK

科学記事のレファレンスと検索

Eric A Swanson: John Wiley, New York, USA

レファレンスおよびアーカイブ利用のためのメ タデータ

Juha Hakala, Helsinki University Library, Finland

7) 产の他の第三機関の寄与

学協会の観点にたった電子出版:一世紀にわたる 旧ミッションを完遂するための21世紀のツール Anthony Durniak: Staff Executive, Publications, Institute of Electrical and Electronics Engineers, USA ライブラリアンの役割の変化 : バーチャルライ ブラリと現実のアーカイブ

J A Klugkist: University of Groningen, the Netherlands

分科会タイトル

1. 経済面での課題

2. 科学杂隹誌の機能と目的

3. 科学者の行動および期待

4. 開発途上国および開発国への移行途中にある国 におけるイニシアチブと発展事項

5. 法的課題

(システム開発部 情報編成技術部門 白木澤佳子) (情報提供部 提供業務課 加藤多恵子) 